Root interactions between intercropped legumes and non-legumes - a competition study of red clover and red beet at different nitrogen levels

Andersen, Sally Nordlund; Dresbøll, Dorte Bodin; Thorup-Kristensen, Kristian

Published in:

Plant and Soil

DOI:

$10.1007 / \mathrm{s} 11104-013-2014-4$

Publication date:

2014

Document version

Early version, also known as pre-print

Citation for published version (APA):

Andersen, S. N., Dresbøll, D. B., \& Thorup-Kristensen, K. (2014). Root interactions between intercropped

legumes and non-legumes - a competition study of red clover and red beet at different nitrogen levels. Plant and Soil, 378(1-2), 59-72. https://doi.org/10.1007/s11104-013-2014-4 


\section{Root interactions between intercropped}

legumes and non-legumes-a competition study of red clover and red beet at different nitrogen levels

\section{Sally Nordlund Andersen, Dorte Bodin Dresbøll \& Kristian Thorup-Kristensen}

\section{Plant and Soil}

An International Journal on Plant-Soil Relationships

ISSN 0032-079X

Volume 378

Combined 1-2

Plant Soil (2014) 378:59-72

DOI 10.1007/s11104-013-2014-4

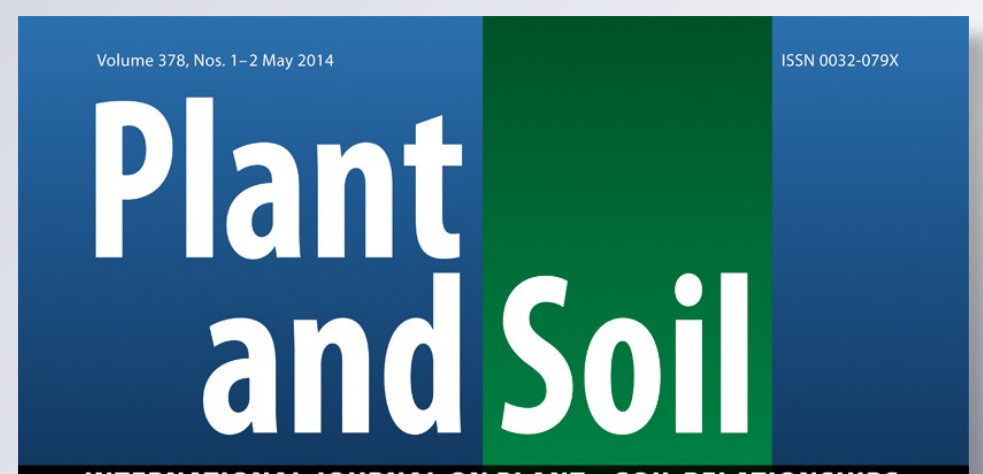

INTERNATIONAL JOURNAL ON PLANT - SOIL RELATIONSHIPS

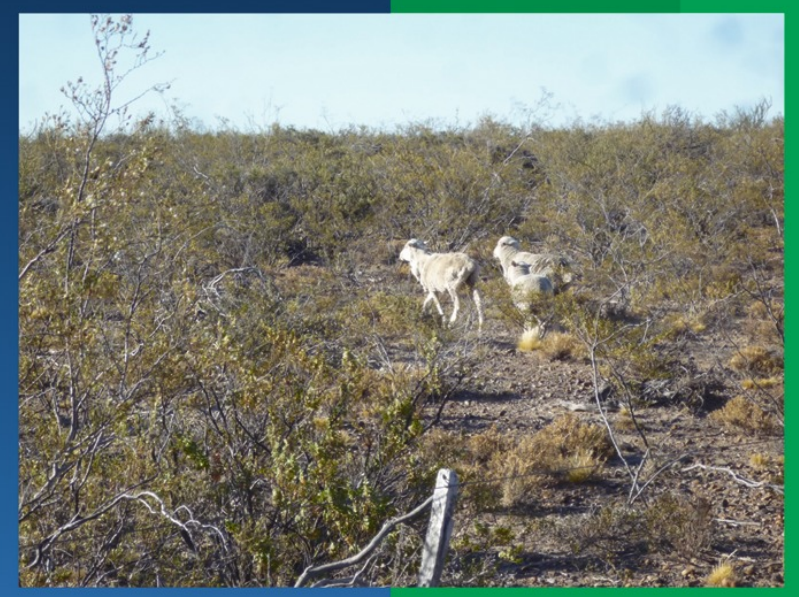

Springer

鱼 Springer 
Your article is protected by copyright and all rights are held exclusively by Springer Science +Business Media Dordrecht. This e-offprint is for personal use only and shall not be selfarchived in electronic repositories. If you wish to self-archive your article, please use the accepted manuscript version for posting on your own website. You may further deposit the accepted manuscript version in any repository, provided it is only made publicly available 12 months after official publication or later and provided acknowledgement is given to the original source of publication and a link is inserted to the published article on Springer's website. The link must be accompanied by the following text: "The final publication is available at link.springer.com". 


\title{
Root interactions between intercropped legumes and non-legumes - a competition study of red clover and red beet at different nitrogen levels
}

\author{
Sally Nordlund Andersen • Dorte Bodin Dresbøll • \\ Kristian Thorup-Kristensen
}

Received: 14 May 2013 / Accepted: 20 December 2013 / Published online: 10 January 2014

(C) Springer Science+Business Media Dordrecht 2014

\begin{abstract}
Aims To investigate root competition in a legume/nonlegume mixture, and how root growth of the legume is affected by the competition at increasing nitrogen $(\mathrm{N})$ supply.

Methods Red beet (Beta vulgaris L.) and red clover (Trifolium pratense L.) were grown in transparent rhizotron tubes either in mixture or as sole crop at $\mathrm{N}$ supplies of 0,75 or $150 \mathrm{~kg} \mathrm{ha}^{-1}$. The root growth was evaluated by the root intensity on the rhizotron surface, root depth and plant uptake of ${ }^{15} \mathrm{~N}$ injected into the soil at the deeper part of the red clover root system.

Results Competition with red beet decreased clover root intensity in deeper soil layers compared to clover grown as sole crop. The difference between clover in sole crop and in mixture was not evident at the highest $\mathrm{N}$ supply because the root growth of clover in sole crop appeared to be lowered at high $\mathrm{N}$ level. Increased $\mathrm{N}$ supply increased the dominance of red beet, but generally did not alter the root growth and distribution of the two species grown in mixture.
\end{abstract}

Responsible Editor: Tim Simon George.

S. N. Andersen • D. B. Dresbøll • K. Thorup-Kristensen $(\square)$ Department of Plant and Environmental Science, University of Copenhagen, Højbakkegårds Alle, 13, 2630 Taastrup, Denmark

e-mail: ktk@plen.ku.dk

S. N. Andersen

e-mail: sallynord@gmail.com

D. B. Dresbøll

e-mail: dbdr@plen.ku.dk
Conclusions Clover root growth and rooting depth were inhibited by competition with red beet but the effect was not enhanced by increased $\mathrm{N}$ supply; hence the increased dominance of red beet at higher $\mathrm{N}$ level was likely due to its increased growth and competitiveness for other soil resources.

Keywords Rhizotron $\cdot$ Root intensity $\cdot{ }^{15} \mathrm{~N}$ uptake Mixed cropping $\cdot$ Land Equivalent Ratio

\section{Introduction}

Growing mixtures of legumes and non-legumes is a common intercropping system (Connolly et al. 2001). A major reason for the success of legume/non-legume intercropping is that they have a higher nitrogen $(\mathrm{N})$-use efficiency compared to growing them solely; both components take up soil mineral-N but the legumes can also fix atmospheric $\mathrm{N}$ in symbiosis with soil bacteria of the genus Rhizobium. This complementary use of $\mathrm{N}$ resources in legume/non-legume mixtures often results in a yield advantage by increasing the overall productivity on the land available compared to growing sole crops (Andersen et al. 2004; Jensen 1996).

Much attention has been given to the effect of $\mathrm{N}$ availability on the performance of components in legume/non-legume intercrops especially in cereal/legume mixtures because the productivity of the cereal component relies heavily on $\mathrm{N}$ input (Ofori and Stern 1986). Increased $\mathrm{N}$ fertilization is regularly observed to favor growth of the non-legume at the expense of the 
legume because the non-legume is a stronger competitor and gets a larger share of the soil N (Andersen et al. 2004; Corre-Hellou et al. 2006; Jensen 1996).

Root interactions have a high impact on the performance of legume/non-legume mixtures (Semere and Froud-Williams 2001; Thorsted et al. 2006), though the interactions between species in a mixture are complex because they involve many different factors that are interrelated. The interactions are further complicated by temporal dynamics, as the competitive performance of the plants change over time. Within a specific crop stand the interactions at any given time are affected by interactions that occurred earlier, e.g. that even small differences in early competition can have a large effect on overall competition during the whole crop development phase.

A major factor determining the uptake and competition for soil resources is the root distribution and occupation of soil space. Genetically different plant species can have different soil exploration strategies (ThorupKristensen 2001), which influence the level of competition between them when grown in the proximity of each other. Plant root growth is also to a great extent determined by the environmental conditions and the presence of neighboring root systems (Hodge 2009). In this way plant root systems may respond to the presence of neighbors by e.g. root segregation where roots avoid each other both within and between root systems (Schenk et al. 1999). Previous experiments in cereal/legume mixtures indicate that the cereal tends to have a faster and deeper root growth and a higher root length density compared to the legume which may contribute to its competitive advantage for soil $\mathrm{N}$ (Corre-Hellou and Crozat 2005; Corre-Hellou et al. 2007; Hauggaard-Nielsen et al. 2001; Katayama et al. 1995; Li et al. 2006). Since the root growth of a plant can be affected by the presence of neighbors, it is possible that the lower performance of the legume is caused by a lowered soil exploration as a response to the presence of the non-legume, and that this competitive effect gets even stronger at higher $\mathrm{N}$ supply. But results on the importance and behavior of roots in legume/nonlegume mixtures are scarce, mainly due to methodological difficulties with differentiating between roots of different plant species.

To determine intra-specific competition belowground the distinction of roots of the competing plant species is necessary. However, root in contrast to aboveground parts show few distinctive external features that permit identification (Fitter 1996). Different methods have been developed for distinguishing between roots of different species, but none of them has yet achieved broad application (Rewald et al. 2012) probably because most of them are destructive and/or very time consuming. As a special case, red beet has been found useful for distinguishing between the root systems in a legume/ non-legume mixture because of its red colored roots (Tosti and Thorup-Kristensen 2010).

While it is difficult to distinguish roots of the different plant species of a mixed stand in the soil, isotopes can be used to study their activity, as has been done with ${ }^{32} \mathrm{P}$ in pea-barley mixtures (Hauggaard-Nielsen et al. 2001) or with ${ }^{15} \mathrm{~N}$ for studying the effect on management on competition between cabbage and various intercrop species (Båth et al. 2008). Even if this method does not allow direct estimates of root density of the competing species, it will allow estimates of the activity of roots in different positions in the soil, and how this is affected by different conditions.

This study provides unique results of root growth in a competitive environment combining a leguminous and a non-leguminous species and varying $\mathrm{N}$ input to the system. The results obtained are the most comprehensive to date as they involve direct dynamic measurements of root growth of each of the two species in a mixture at high spatial and temporal resolution, and confirm part of these root observations through functional root studies in terms of deep ${ }^{15} \mathrm{~N}$ uptake. The aims of the present study were (i) to investigate the effect of root interactions on the root foraging behavior of the mixture components in a legume/non-legume mixture; (ii) to test if $\mathrm{N}$ fertilization affects the root growth especially of the legume in a legume/non-legume mixture; (iii) to test if the root interaction between the two components of the intercrop varies over time and in different soil depths.

\section{Materials and methods}

Experimental setup

This experiment was conducted during 23 June-13 September at The University of Copenhagen in Taastrup, Denmark $\left(55^{\circ} 40^{\prime} \mathrm{N} ; 12^{\circ} 18^{\prime} \mathrm{E}\right)$. Light conditions were similar to within a greenhouse without artificial light and average temperature and humidity in June, July, August and September was 16, 17, 17 and $14{ }^{\circ} \mathrm{C}$ and $77,86,85$ and $86 \%$, respectively. 
The experiment compared growth of shoot and root of red beet (Beta vulgaris L. cv. Taunus) and red clover (Trifolium pratense L. cv. 'Kvarta') grown in pure stands or in mixtures at three different $\mathrm{N}$ fertilizer levels in rhizotron tubes. The experiment included 27 experimental units, three crop compositions (red beet, red clover or mixture of the two), three $\mathrm{N}$ levels and three replicates, arranged in a completely randomized block design. Within each rhizotron tube two plants were grown; two red beets, two red clover or mixtures with one of each, i.e. studying the competition by a replacement design. The rhizotron tubes were 2-m high transparent plastic tubes with an inner diameter of $104 \mathrm{~mm}$ and an outer diameter of $110 \mathrm{~mm}$. The bottom of the tubes was covered with a plastic net to hold back the soil while allowing flow of water and air. The rhizotron tubes were covered in non-transparent plastic to avoid light exposure of the soil and the roots.

Seeds of red beet and red clover were sown in $16 \mathrm{~cm}^{3}$ Jiffy pots (Jiffy A/S, Denmark) in a greenhouse. Six days after sowing the two species were thinned to contain only two seedlings per pot. One week after sowing, the pots were transplanted to rhizotron tubes that were placed outdoors, but underneath a glass roof. Four days after transplanting all transplants were thinned to leave two plants per rhizotron tube. 28 days after transplanting a polyethylene mesh $(1.3 \mathrm{~mm} \times 1.3 \mathrm{~mm})$ was setup between and around the plants to minimize effects of aboveground competition.

The two species were grown as sole crop (clover/ clover and beet/beet) and in mixture (clover/beet and beet/clover) at either low, medium or high nitrogen supply. In the designations for the plant species combinations the first underlined name indicates the plant that was measured and the second name indicates which plant it was grown with.

\section{Growing medium}

To ensure a low level of nitrogen the growing medium was based on soil from the lower horizon $(20-60 \mathrm{~cm})$ of an organically grown arable field, a sandy loam (Agrudalf), at The University research farm in Taastrup, Denmark. This soil was then mixed with washed sand (33\% in volume) and sieved through a 5 -mm sieve and homogenized. The final texture of the soil was $63.2 \%$ coarse sand, $25.3 \%$ fine sand, $5.8 \%$ silt, $4.2 \%$ clay and $1.5 \%$ humus, and this soil will have a field capacity corresponding to $\sim 10 \% \mathrm{w} / \mathrm{w}$ (Saxton and Rawls 2006). The amount of $\mathrm{KCl}$-extractable $\mathrm{NO}_{3}-\mathrm{N}$ was $6.6 \mathrm{mg} \mathrm{kg}^{-1}$.

The soil was packed by hand into the rhizotron tubes by adding approx. $250 \mathrm{ml}$ at a time before ramming it with a metal piston. This was done to approach the high bulk densities found under field conditions and to prevent the soil from parting/cracking at desiccation creating layers of air in the soil column which would affect the root growth. The final bulk density was $1.5 \mathrm{Mg} \mathrm{m}^{-3}$ in the top $(18 \mathrm{~cm})$ and $1.6 \mathrm{Mg} \mathrm{m}^{-3}$ in the bottom $(12 \mathrm{~cm})$ of the tubes. With an average bulk density of $1.55 \mathrm{Mg} \mathrm{m}^{-3}$ the total soil dry weight per column was $25.8 \mathrm{~kg}$.

\section{Irrigation and fertilization}

Before transplanting the soil was irrigated to field capacity through a soaker hose (Park Garden, Denmark) to minimize movement of nutrients and soil particles in the rhizotron tubes. The soaker hose was permanently installed vertically inside the soil column along the edge of the tubes. The top soil was irrigated subsequently by adding $250 \mathrm{ml}$ water at the soil surface. After transplanting the tubes were given $200 \mathrm{ml}$ water to moisten the soil followed by $25 \mathrm{ml}$ of a nutrient solution. The nutrient solution contained dissolved $\mathrm{NH}_{4} \mathrm{NO}_{3}$ in the amounts of 0, 64 and $128 \mathrm{mg} \mathrm{N}$ per tube for the low, medium and high nitrogen treatments, respectively, which correspond to 0,75 and $150 \mathrm{~kg} \mathrm{~N} \mathrm{ha}^{-1}$ calculated using the cross sectional area of the tubes. Additionally, all treatments were given extra $\mathrm{P}$ and $\mathrm{K}$ in the amounts of 17 and $43 \mathrm{mg}$ per tube which is $20 \mathrm{~kg} \mathrm{P} \mathrm{ha}^{-1}$ and $50 \mathrm{~kg} \mathrm{~K} \mathrm{ha}^{-1}$. As the soil was collected from a fertile arable soil only the major macronutrients were added comparable to production under field conditions.

In addition to the water given before transplanting, the rhizotron tubes were irrigated ten times by hand during the experiment with a total amount of water of $950 \mathrm{ml}$ (equivalent to $112 \mathrm{~mm}$ rainfall) to mimic the average expected rainfall in the area. No leaching from the tubes was observed at any point during the experiment.

Injection of ${ }^{15} \mathrm{~N}$

After the final root measurements at 79 days after transplanting and 3 days before final harvest, ${ }^{15} \mathrm{~N}$ was injected into the tubes. A ${ }^{15} \mathrm{~N}$-enriched solution was injected into each tube at $0.62 \mathrm{~m}$ depth. The depth of injection was close to the bottom of the red clover root system, and the amount of ${ }^{15} \mathrm{~N}$ to be so high that the 
plants were only likely to take up a fraction of it during 3 days, thereby avoiding significant competition for it.

For ${ }^{15} \mathrm{~N}$ injection, two holes were made with a $5-\mathrm{mm}$ drill at a distance of $86 \mathrm{~mm}$ to each other and $0.62 \mathrm{~m}$ below the soil surface in each rhizotron tube. The ${ }^{15} \mathrm{~N}$ solution was prepared by dissolving $\mathrm{NH}_{4}{ }^{15} \mathrm{NO}_{3}(98$ atom $\%{ }^{15} \mathrm{~N}$ ) and $\mathrm{NH}_{4} \mathrm{NO}_{3}$ in deionized water making a final solution of $7.9 \mathrm{mmol} \mathrm{l}^{-1} \mathrm{NH}_{4}{ }^{15} \mathrm{NO}_{3}$ and $33.2 \mathrm{mmol} \mathrm{l}^{-1} \mathrm{NH}_{4} \mathrm{NO}_{3}$. The choice of using labeled nitrate was based on the mobility of $\mathrm{NO}_{3}{ }^{-}$in soil ensuring a continuous diffusion to the roots in contrast to the much less mobile $\mathrm{NH}_{4}{ }^{+}$. Furthermore, nitrification from $\mathrm{NH}_{4}{ }^{+}$to $\mathrm{NO}_{3}{ }^{-}$will typically occur fast in the soil. Through each hole in the tubes $15 \mathrm{ml}$ of the ${ }^{15} \mathrm{~N}$ solution was injected into the soil column with a syringe (Fig. 1), which was sealed with rubber to avoid spill/outflow. A test injection with a stained solution revealed that the ${ }^{15} \mathrm{~N}$ solution could be expected to be distributed fairly even in the soil layer $0.02 \mathrm{~m}$ above and below injection depth (i.e. $0.60-0.64 \mathrm{~m}$ ). The total injected amount was $4 \mathrm{mg}{ }^{15} \mathrm{~N}$ per tube and $41 \mathrm{~kg} \mathrm{~N}^{-1}{ }^{-1}$.

When calculating ${ }^{15} \mathrm{~N}$ uptake, the ${ }^{15} \mathrm{~N}$ enrichment of the plant material was corrected for the ambient ${ }^{15} \mathrm{~N}$ concentration in the atmosphere:

${ }^{15}$ Nuptake $=\left(\frac{{ }^{15} N}{N}\right.$ sample -0.3663$) \times$ Nsample

where $\frac{{ }^{15} N}{N}$ sample is the ${ }^{15} \mathrm{~N}$ concentration in a plant sample, 0.3663 is the ${ }^{15} \mathrm{~N}$ concentration of the

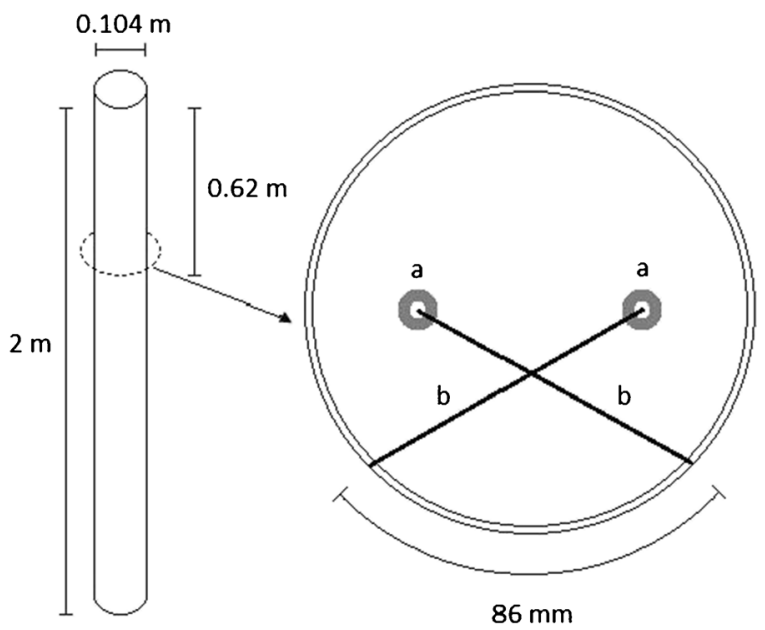

Fig. 1 Schematic drawing of the rhizotron tube with specification of inner dimensions and the ${ }^{15} \mathrm{~N}$ injection method. The letters indicate $\mathbf{a}$ the injection site for the ${ }^{15} \mathrm{~N}$ solution and $\mathbf{b}$ the angle of the syringe needle in the tubes atmosphere and Nsample is the total $\mathrm{N}$ uptake in the given plant sample. It was assumed that the natural ${ }^{15} \mathrm{~N}$ concentration in the plant tissue corresponded to the ${ }^{15} \mathrm{~N}$ concentration in the atmosphere because the primary $\mathrm{N}$ sources was either from atmospheric $\mathrm{N}$ fixation or uptake of mineral fertilizer, the latter having a ${ }^{15} \mathrm{~N}$ concentration close to the atmospheric (Vitoria et al. 2004).

\section{Root measurements}

For root measurements, transparent plastic sheets with a grid of $20 \mathrm{~mm} \times 20 \mathrm{~mm}$ squares were placed on the rhizotron surface in the opposite side of the soaker hose. Root intensity (RI) was assessed by counting the number of observed root crossings per meter grid line as it was done by Tosti and Thorup-Kristensen (2010). Root depth was estimated as the deepest root crossing observed. Roots of red beet were distinguished from roots of red clover by their color: red beet roots were pink/purple and clover roots were white.

Root assessments were performed 18, 20, 22, 25, 29, 36, 43, 50, 61 and 75 days after transplanting. Root observations were made in all depths from the soil surface until $1.85 \mathrm{~m}$ at every assessment. The experiment was stopped when the first roots started to reach the bottom of the tubes. Time was evaluated as thermal time expressed as accumulated daily average temperature from transplanting (day ${ }^{\circ} \mathrm{C}$ ) calculated with a base temperature of $0{ }^{\circ} \mathrm{C}$.

Plant sampling and analysis

The plants were harvested 82 days after transplanting. Red clover was cut at the soil surface and red beet was harvested with the tap root. The plant material was washed and dried at $80{ }^{\circ} \mathrm{C}$ for $24 \mathrm{~h}$ to determine dry weight.

Before analysis the plant material was freeze-dried for $24 \mathrm{~h}$ before it was ground in an Ultra Centrifugal Mill ZM 200 (Retsch GmbH, Germany) with a sieve size of $0.2 \mathrm{~mm}$ for red clover and $0.5 \mathrm{~mm}$ for the red beet plant material. Total $\mathrm{N}$ and ${ }^{15} \mathrm{~N}$ contents were determined on $4.5-5 \mathrm{mg}$ of the ground material using Isotope Ratio-Mass Spectrometry (IR-MS) (PDZ Europa Ltd, Crewe, UK).

Calculations and statistical analysis

Most data are presented as single plant data. In the intercropped treatments this was the direct measured 
data, but in the sole crop situations (clover/clover and beet/beet) single plant data were calculated as half the directly measured value.

The statistical program $R$ (R Development Core Team 2011) was used to make the statistical analysis. Effects of cropping method ('species') $(S)$ and nitrogen treatment ('treat') $(N)$ was tested using the general linear model procedure. Data were tested with a linear relationship between treatment and species if data were found to show normal distribution. Data were transformed by raise to the power of 0.4 if assumption of normality or homogeneity of variances was not fulfilled. Comparisons between results were based on least significant difference (LSD) values derived from the analysis of variance. Tests with $p \leq 0.05$ were considered statistically significant. When presenting data in figures, RI values were subjected to a natural logarithmic transformation and in order to do so, zero observations were given a value corresponding to $25 \%$ of the smallest measurable value in the given soil volume.

To assess the advantage of intercropping the Land Equivalent Ratio (LER) was calculated as the sum of the partial LER value of red beet $\left(L_{\mathrm{b}}\right)$ and red clover $\left(L_{\mathrm{c}}\right)$ (Ofori and Stern 1987b):

$L E R=L_{b}+L_{c}=\frac{Y_{b c}}{Y_{b b}}+\frac{Y_{c b}}{Y_{c c}}$

where $Y_{\mathrm{bc}}$ and $Y_{\mathrm{cb}}$ are the yields per unit area of intercropped red beet and red clover and $Y_{\mathrm{bb}}$ and $Y_{\mathrm{cc}}$ are the yields per hectare of red beet and red clover grown as sole crops.

\section{Results}

The biomass of red clover was significantly reduced when in competition with red beet at medium and high $\mathrm{N}$ supply (Table 1 ). Red beet was positively affected by the intercrop as the biomass of Rc was significantly higher than $\mathrm{Rr}$ at all $\mathrm{N}$ treatments (Table 1). The relative dry matter loss for clover in competition with red beet was increased with increasing $\mathrm{N}$ supply (14\%, $45 \%$ and $52 \%$ at low, medium and high $\mathrm{N}$ supply respectively) but it was never as high as the relative dry matter gain of red beet when in mixture compared to monocrop (46\%, $67 \%$ and $84 \%$ for low medium and high $\mathrm{N}$ supply, respectively).

Differences in $\mathrm{N}$ uptake per plant within species were similar to the differences in biomass at harvest; the $\mathrm{N}$ uptake per plant was lowered in clover and increased in red beet when grown in mixture compared to the sole crop situation and the relative loss/gain was increased with increasing $\mathrm{N}$ supply (Table 1 ). Nitrogen uptake in clover was considered a sum of mineral $\mathrm{N}$ uptake from the soil and $\mathrm{N}$ fixation from the atmosphere as root nodules were observed on all clover root systems. The added amount of mineral $\mathrm{N}$ was $64 \mathrm{mg} \mathrm{N}^{\mathrm{N}}$ tube $^{-1}$ and $127 \mathrm{mg} \mathrm{N}$ tube $^{-1}$ at the medium and high $\mathrm{N}$ treatment

Table 1 Aboveground dry matter and $\mathrm{N}$ uptake per plant and total and partial land equivalent ratio for biomass and $\mathrm{N}$ uptake at harvest

\begin{tabular}{|c|c|c|c|c|c|c|c|c|}
\hline & \multicolumn{4}{|c|}{ Biomass (mg plant ${ }^{-1}$ ) } & \multicolumn{4}{|c|}{$\mathrm{N}$ uptake (mg plant ${ }^{-1}$ ) } \\
\hline & $0 \mathrm{~kg} \mathrm{~N} \mathrm{ha}^{-1}$ & $75 \mathrm{~kg} \mathrm{~N} \mathrm{ha}^{-1}$ & $150 \mathrm{~kg} \mathrm{~N} \mathrm{ha}^{-1}$ & & $0 \mathrm{~kg} \mathrm{~N} \mathrm{ha}^{-1}$ & $75 \mathrm{~kg} \mathrm{~N} \mathrm{ha}^{-1}$ & $150 \mathrm{~kg} \mathrm{~N} \mathrm{ha}^{-1}$ & \\
\hline Clover/clover & $1,773 \mathrm{a}$ & $2,042 \mathrm{~b}$ & $2,112 b$ & $\mathrm{~ns}$ & $52.5 \mathrm{a}$ & $58.8 \mathrm{~b}$ & $59.4 \mathrm{~b}$ & $\mathrm{~ns}$ \\
\hline Clover/beet & $1,533 \mathrm{a}$ & $1,123 \mathrm{a}$ & $1,010 \mathrm{a}$ & ns & $45.3 \mathrm{a}$ & $36.2 \mathrm{a}$ & $30.6 \mathrm{a}$ & $\mathrm{a}$ \\
\hline$\underline{\text { Beet/clover }}$ & $3,980 \mathrm{~b}$ & $6,400 \mathrm{~d}$ & $8,560 \mathrm{~d}$ & a & $84.8 \mathrm{~b}$ & $123.2 \mathrm{~d}$ & $187.7 \mathrm{~d}$ & a \\
\hline Beet/beet & $2,720 \mathrm{a}$ & $3,828 \mathrm{c}$ & $4,650 \mathrm{c}$ & a & $53.3 \mathrm{a}$ & $69.3 \mathrm{c}$ & $92.1 \mathrm{c}$ & $\mathrm{a}$ \\
\hline \multicolumn{9}{|c|}{$\overline{\text { Land }}$ equivalent ratio } \\
\hline$L_{\text {clover }}$ & $0.44 \mathrm{a}$ & $0.29 \mathrm{a}$ & $0.24 \mathrm{a}$ & a & $0.43 \mathrm{a}$ & $0.32 \mathrm{a}$ & $0.26 \mathrm{a}$ & a \\
\hline$L_{\text {beet }}$ & $0.74 \mathrm{~b}$ & $0.86 \mathrm{~b}$ & $0.92 \mathrm{~b}$ & ns & $0.80 \mathrm{~b}$ & $0.90 \mathrm{~b}$ & $1.04 \mathrm{~b}$ & ns \\
\hline LER & 1.18 & 1.15 & 1.16 & $\mathrm{~ns}$ & 1.23 & 1.22 & 1.30 & ns \\
\hline
\end{tabular}

Data was measured on the underlined species when grown in mixture with the species written in plain text. Significant effect of the interaction between cropping method and N treatment $(S \times N)$ was found for biomass $(p<0.05)$ and N uptake $(p<0.001)$. Numbers followed by different letters are significantly different $(p<0.05)$ within each $\mathrm{N}$ treatment

${ }^{\text {a }}$ Indicate a significant effect of N supply 
Table $2 \mathrm{~N}$ and ${ }^{15} \mathrm{~N}$ concentration at harvest in the aboveground dry matter. Data were obtained on the underlined species when grown in mixture with the species written in plain text. There were no significant effects $(p>0.05)$ of the interaction between cropping method and $\mathrm{N}$ treatment $(S \times N)$, while for $\mathrm{N}$ concentration there was a significant effect of cropping method $(S)(p<0.001)$ and no effect of $\mathrm{N}$ treatment $(p>0.05)$ and for ${ }^{15} \mathrm{~N}$ concentration there was significant effect of cropping method and $\mathrm{N}$ treatment $(S+N)$ $(p<0.001)$. Numbers followed by different letters are significantly different $(p<0.05)$ within each $\mathrm{N}$ treatment

\begin{tabular}{|c|c|c|c|c|c|c|}
\hline & \multicolumn{3}{|c|}{$\mathrm{N}$ concentration $\left(\mathrm{mg} \mathrm{g}^{-1}\right)$} & \multicolumn{3}{|c|}{${ }^{15} \mathrm{~N}$ concentration $(\%$ of total $\mathrm{N})$} \\
\hline & $0 \mathrm{~kg} \mathrm{~N} \mathrm{ha}^{-1}$ & $75 \mathrm{~kg} \mathrm{~N} \mathrm{ha}^{-1}$ & $150 \mathrm{~kg} \mathrm{~N} \mathrm{ha}^{-1}$ & $0 \mathrm{~kg} \mathrm{~N} \mathrm{ha}^{-1}$ & $75 \mathrm{~kg} \mathrm{~N} \mathrm{ha}^{-1}$ & $150 \mathrm{~kg} \mathrm{~N} \mathrm{ha}^{-1}$ \\
\hline Clover/clover & $29.7 \mathrm{~b}$ & $29.0 \mathrm{~b}$ & $28.3 \mathrm{~b}$ & $0.40 \mathrm{~b}$ & $0.40 \mathrm{~b}$ & $0.42 \mathrm{~b}$ \\
\hline Clover/beet & $29.8 \mathrm{c}$ & $32.4 \mathrm{c}$ & $30.3 \mathrm{c}$ & $0.38 \mathrm{a}$ & $0.37 \mathrm{a}$ & $0.37 \mathrm{a}$ \\
\hline$\underline{\text { Beet/clover }}$ & $21.2 \mathrm{a}$ & $19.3 \mathrm{a}$ & $21.9 \mathrm{a}$ & $0.50 \mathrm{c}$ & $0.51 \mathrm{c}$ & $0.46 \mathrm{c}$ \\
\hline Beet/beet & $19.7 \mathrm{a}$ & $18.3 \mathrm{a}$ & $19.9 \mathrm{a}$ & $0.51 \mathrm{c}$ & $0.54 \mathrm{c}$ & $0.50 \mathrm{c}$ \\
\hline
\end{tabular}

respectively and the measured total $\mathrm{N}$ uptake in the aboveground biomass in excess of the added was 8 $54 \mathrm{mg}$ in clover sole crop, 57-75 mg in red beet sole crop and $91-95 \mathrm{mg}$ in the mixture. The $\mathrm{N}$ concentration in the aboveground plant biomass was not significantly affected by $\mathrm{N}$ supply and varied mostly between species (Table 2).

The Land Equivalent Ratio (LER) for both biomass and $\mathrm{N}$ uptake was higher than one at all $\mathrm{N}$ levels (Table 1), and LER for $\mathrm{N}$ uptake was higher than LER for biomass. This shows that more biomass and $\mathrm{N}$ could be harvested by growing the crops in mixture than by growing them as sole crops on the same area.
Red beet root growth was faster than clover root growth as the root intensity (RI) per plant during the initial growth stage $\left(324-438\right.$ day $\left.{ }^{\circ} \mathrm{C}\right)$ was higher in red beet (beet/beet and beet/clover) compared to red clover (clover/beet and clover/clover) (Fig. 2). Red beet also had a significantly $(p<0.05)$ faster root depth penetration rate than clover independent of cropping method and $\mathrm{N}$ supply (Tables 3 and 4) and from the second measuring date until harvest red beet roots grew significantly $(p<0.05)$ deeper than clover independent of cropping method (Fig. 3).

The root growth dynamics varied between soil depths and the relationship between the species changed over
$0 \mathrm{~kg} \mathrm{~N} \mathrm{ha}^{-1}$

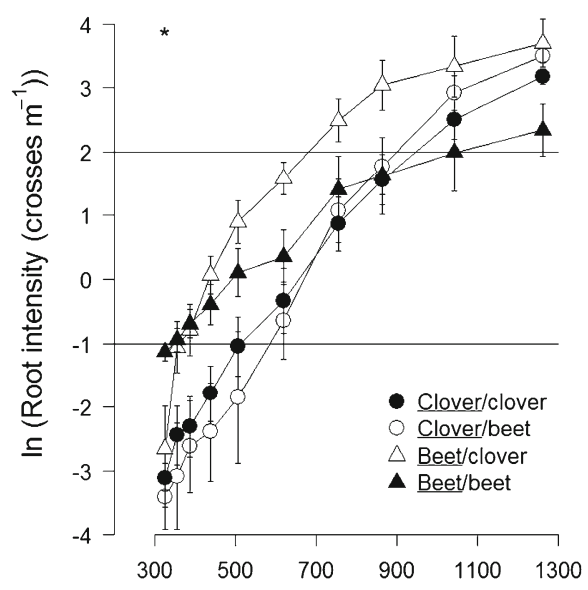

$75 \mathrm{~kg} \mathrm{~N} \mathrm{ha}^{-1}$

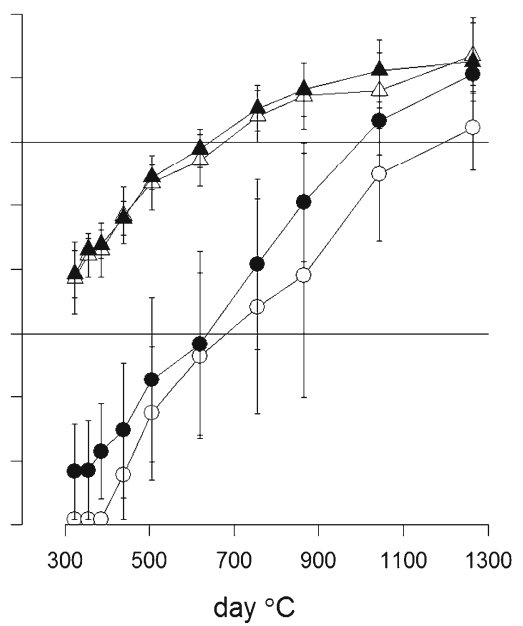

$150 \mathrm{~kg} \mathrm{~N} \mathrm{ha}^{-1}$

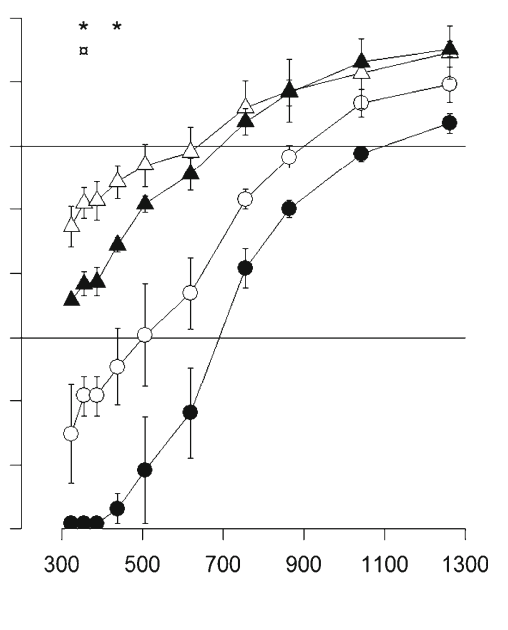

Fig. 2 Total root intensity per plant in the whole soil column (0$1.8 \mathrm{~m}$ ) as a function of thermal time (day ${ }^{\circ} \mathrm{C}$ from transplanting) at low, medium and high $\mathrm{N}$ supply. Data were obtained on the underlined species when grown in mixture with the species written in plain text. ' $*$ ' indicate significant difference $(p<0.05)$ between beet/clover and beet/beet and ' $a$ ' indicate significant difference $\overline{(p<0.05)}$ between clover/clover and clover/beet at dates with a

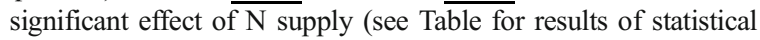
analysis). Bars represent the mean $\pm \mathrm{SE}$ 
Table 3 Results of the statistical analysis performed on each of the ten measuring dates expressed in thermal time (day ${ }^{\circ} \mathrm{C}$ from transplanting)

Total root intensity per plant
(Figure 2 )
Root depth
(Figure 3 )
Total root intensity per tube
(Figure 5)
Root intensity, top
(Figure 4a)
Root intensity, middle
(Figure 4b)
Root intensity, bottom
(Figure 4c)

\begin{tabular}{|c|c|c|c|c|c|c|c|c|c|}
\hline \multicolumn{10}{|c|}{ day ${ }^{\circ} \mathrm{C}$} \\
\hline 324 & 355 & 387 & 438 & 506 & 619 & 756 & 864 & 1043 & 1263 \\
\hline \multicolumn{4}{|c|}{$S \times N$} & \multicolumn{4}{|c|}{$S$} & \multicolumn{2}{|c|}{ ns } \\
\hline \multicolumn{6}{|c|}{$S \times N$} & \multicolumn{4}{|c|}{$S$} \\
\hline \multicolumn{5}{|c|}{$S \times N$} & \multicolumn{3}{|c|}{$S$} & ns & $S \times N$ \\
\hline \multicolumn{4}{|c|}{$S \times N$} & \multicolumn{3}{|c|}{$S$} & ns & \multicolumn{2}{|c|}{$S$} \\
\hline & & & & $S \times N$ & $S+N$ & \multicolumn{3}{|c|}{$S$} & $S \times N$ \\
\hline & & & & & & & \multicolumn{3}{|c|}{$S$} \\
\hline
\end{tabular}

Two way anova was performed with systematic effect of cropping method $(S)$ and $\mathrm{N}$ treatment $(N)$ each containing four and three levels respectively except for total root intensity per tube where the species combination only had three levels. The figure indicates significant effects $(p \leq 0.05)$ of the interaction $(S \times N)$, the sum of both main effects $(S+N)$ or only one main effect $(S$ or $N)$ and if there was no significant effect at all (ns)

time (Fig. 4). In the top soil layer $(0.02-0.50 \mathrm{~m})$ the RI of red beet increased fast during early growth, but then leveled out and started to decrease (Fig. 4), while the RI of clover increased more slowly during early stages, but continued to increase during the whole experiment. Because of this, red beet roots dominated the top soil layer until around 1,000 day ${ }^{\circ} \mathrm{C}$, but after this, red clover had the highest RI in the top soil layer, also in the mixtures. In both the middle and the bottom soil layer red beet arrived before red clover and dominated until the final measuring date (Fig. 4b, c).

A combined effect of cropping method and $\mathrm{N}$ supply initially had a significant effect on the total RI and root

Table 4 Average root depth penetration rate $\left(\mathrm{mm} \mathrm{day}{ }^{-1}{ }^{\circ} \mathrm{C}^{-1}\right)$ during plant growth (from 355 to 1,043 day ${ }^{-1}{ }^{\circ} \mathrm{C}^{-1}$ )

\begin{tabular}{llll}
\hline & $0 \mathrm{~kg} \mathrm{~N} \mathrm{ha}$ & $75 \mathrm{~kg} \mathrm{~N} \mathrm{ha}^{-1}$ & $150 \mathrm{~kg} \mathrm{~N} \mathrm{ha}^{-1}$ \\
\hline Clover/clover & $0.76 \mathrm{a}$ & $0.94 \mathrm{a}$ & $0.75 \mathrm{a}$ \\
Clover/beet & $0.72 \mathrm{a}$ & $0.50 \mathrm{a}$ & $0.61 \mathrm{a}$ \\
Beet/clover & $1.47 \mathrm{~b}$ & $1.16 \mathrm{~b}$ & $1.26 \mathrm{~b}$ \\
Beet/beet & $1.40 \mathrm{~b}$ & $1.50 \mathrm{~b}$ & $1.44 \mathrm{~b}$ \\
\hline
\end{tabular}

Data were obtained on the underlined species when grown in mixture with the species written in plain text. The effect of $\mathrm{N}$ treatment was non-significant $(p>0.05)$ and the effect of cropping method was significant $(p<0.001)$. Numbers followed by different letters are significantly different $(p<0.05)$ within each $\mathrm{N}$ treatment depth but these differences disappeared after 438 day ${ }^{\circ} \mathrm{C}$ (Table 3). Still red beet ended up with a total RI that was four times higher when grown in intercrop compared to sole crop at low N supply while there was no difference in the final RI between the two cropping methods at medium and high $\mathrm{N}$ supply (Fig. 2). The low root growth of red beet in sole crop at low $\mathrm{N}$ compared to medium and high $\mathrm{N}$ supply was also evident when looking at the total root production per rhizotron tube (Fig. 5). Clover sole crop on the other hand expressed a decreased root growth at the high $\mathrm{N}$ level during the experiment, which resulted in a final total RI in each rhizotron tube that was less than half the size of the RI found at medium and low $\mathrm{N}$ supply $\left(21.6\right.$ crosses $\mathrm{m}^{-1}$ at $150 \mathrm{~kg} \mathrm{~N}^{-1}$ compared to 48.9 crosses $\mathrm{m}^{-1}$ at $0 \mathrm{~kg} \mathrm{~N} \mathrm{ha}^{-1}$ and 45.7 crosses $\mathrm{m}^{-1}$ at $75 \mathrm{~kg} \mathrm{~N} \mathrm{ha}^{-1}$ ). Also the root depth of clover in sole crop was decreased with increasing $\mathrm{N}$ supply $\left(p<0.05\right.$ at $355-506$ day ${ }^{\circ} \mathrm{C}$ ) while the root depth of clover in mixture was unchanged.

The altered competition in the mixture caused clover roots to grow less deep compared to clover grown as sole crop, at the end of the experiment the difference was $0.21 \mathrm{~m}, 0.53 \mathrm{~m}$ and $0.04 \mathrm{~m}$ difference at low, medium and high $\mathrm{N}$ supply respectively. This also affected the RI in the middle soil layer where clover in mixture ended up with a significantly lower RI 


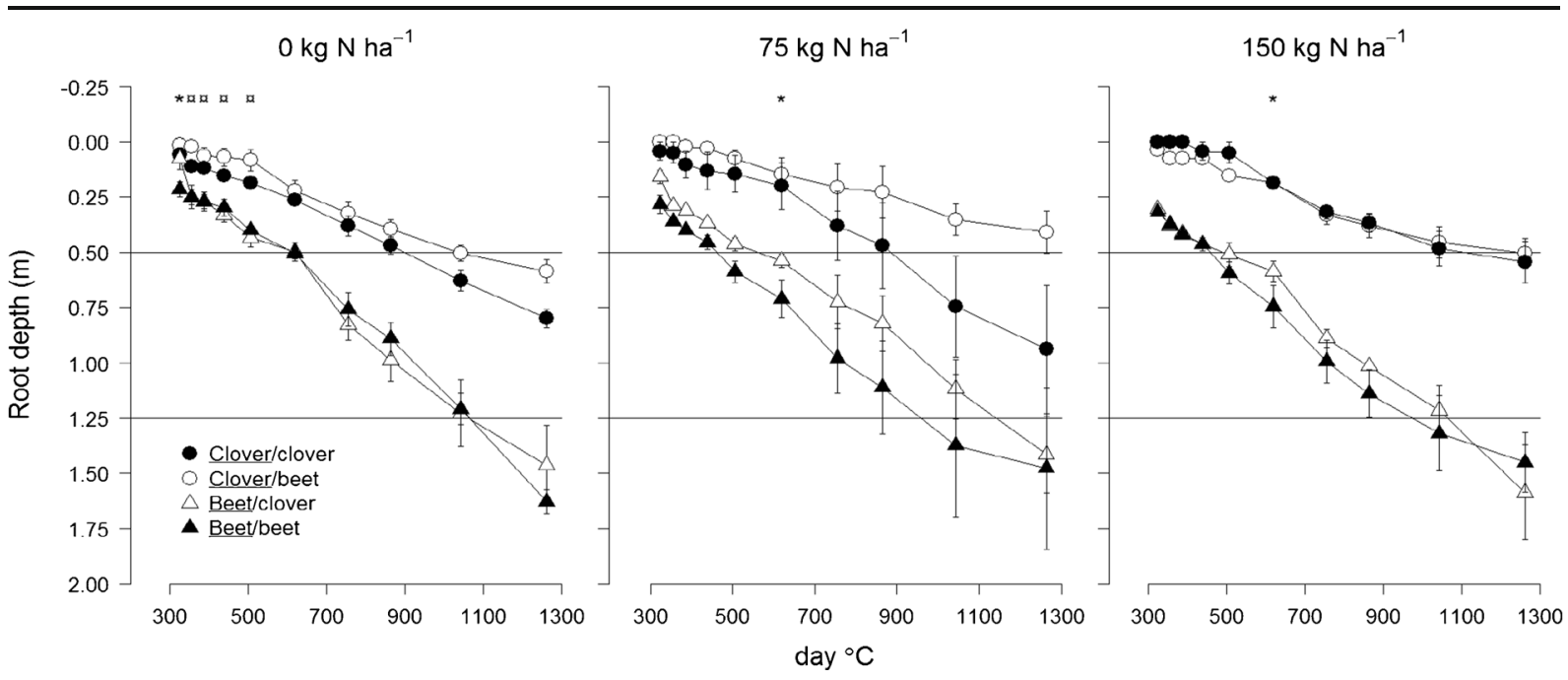

Fig. 3 Root depth as the deepest detected root crossing as a function of thermal time (day ${ }^{\circ} \mathrm{C}$ from transplanting) at low, medium and high $\mathrm{N}$ supply. Data were obtained on the underlined species when grown in mixture with the species written in plain text. ' $*$ ' indicate significant difference $(p<0.05)$ between beet/

compared to sole crop at low and medium $\mathrm{N}$ supply, while at the high $\mathrm{N}$ supply this difference was not significant because of a decreased RI of clover sole crop (Fig. 4b). Red beet root growth was less altered in the mixture. Red beet grown as sole crop entered the middle soil layer later at low $\mathrm{N}$ compared to medium and high $\mathrm{N}$ and had a lower RI during the whole experiment at low $\mathrm{N}$, which resulted in a significant difference between beet/beet and beet/clover in the end (Fig. 4b). When intercropped the total root production was higher at low and high $\mathrm{N}$ supply than what could be expected from the root growth of the two species grown as sole crops and this was evident almost during the entire growing period (Fig. 5).

The final root activity around the lower part of the clover root system was also measured by ${ }^{15} \mathrm{~N}$ uptake. ${ }^{15} \mathrm{~N}$ was injected at a soil depth where the clover root growth seemed to be inhibited by the red beet (clover/ beet had a lower RI than clover/clover at all $\mathrm{N}$ treatments) (Fig. 6). Though there was a high variation in the $\mathrm{RI}$ around the injection site the general trend in root growth within species corresponded with the ${ }^{15} \mathrm{~N}$ uptake. Red beet in mixture had a higher RI and ${ }^{15} \mathrm{~N}$ uptake than red beet grown as sole crop at all $\mathrm{N}$ levels while clover in mixture had a lower ${ }^{15} \mathrm{~N}$ uptake and RI than clover grown as sole crop at all $\mathrm{N}$ levels (Fig. 6). Clover in mixture was hardly present in the soil at injection depth at medium and high $\mathrm{N}$ supply (0 and 1 crosses clover and beet/beet and ' $a$ ' indicate significant difference $(p<0.05)$ between clover/clover and clover/beet at dates with a significant effect of $\mathrm{N}$ supply (see Table 3 for results of statistical analysis). Bars represent the mean $\pm \mathrm{SE}$

$\mathrm{m}^{-1}$ on average) which resulted in a very low ${ }^{15} \mathrm{~N}$ uptake $(0.7 \mu \mathrm{g}$ and $0.3 \mu \mathrm{g})$.

The amount of ${ }^{15} \mathrm{~N}$ added to each soil column was $4 \mathrm{mg}$ and on average 1-6\% of this was measured as plant uptake in the aboveground plant biomass in each rhizotron tube. The ${ }^{15} \mathrm{~N}$ concentration in the aboveground dry matter of red beet was higher than in clover (Table 2).

\section{Discussion}

The interactions between legumes and non-legumes in the experiment resembled what is normally found in intercrop experiments: that the Land Equivalent Ratio (LER) for biomass was greater than 1 (Table 1), showing that the intercrops were more productive compared to the monocrops (Vandermeer 1989; Ofori and Stern 1987b). The partial LER for both biomass and $\mathrm{N}$ uptake of red beet was significantly higher than the partial LER of clover, and the difference between them increased with increasing $\mathrm{N}$ supply, meaning that red beet benefited relatively more from being intercropped and this advantage increased with increasing $\mathrm{N}$ supply. The positive yield response of the non-legume and the negative or stagnated response of the legume to increased $\mathrm{N}$ supply is a common observation in legume/non-legume intercrops (Andersen et al. 2004; Morgado and Willey 2003; Ofori 


\section{$0 \mathrm{~kg} \mathrm{~N} \mathrm{ha}{ }^{1}$}

a
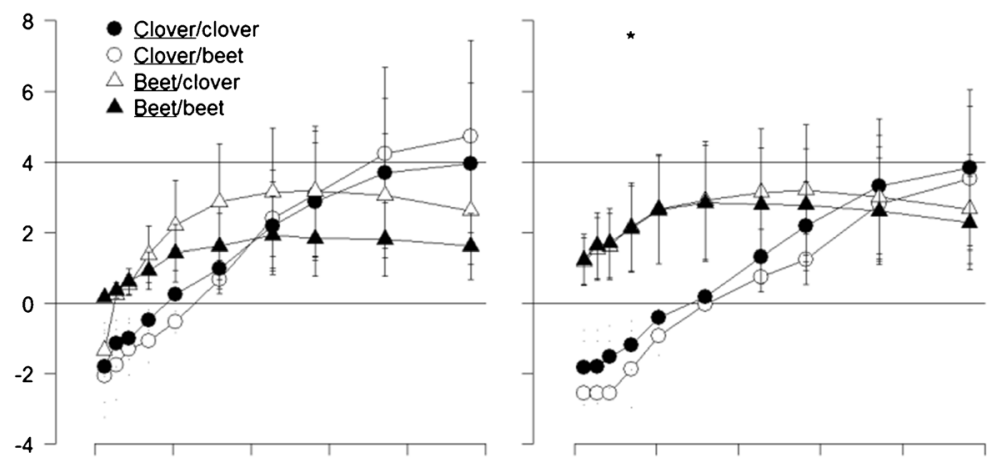

$75 \mathrm{~kg} \mathrm{~N}$ ha ${ }^{1}$

$150 \mathrm{~kg} \mathrm{~N}$ ha ${ }^{1}$

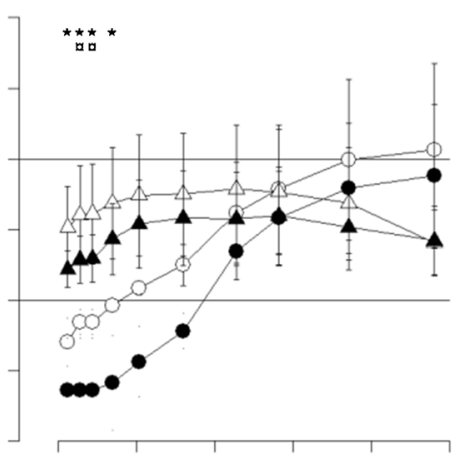

b
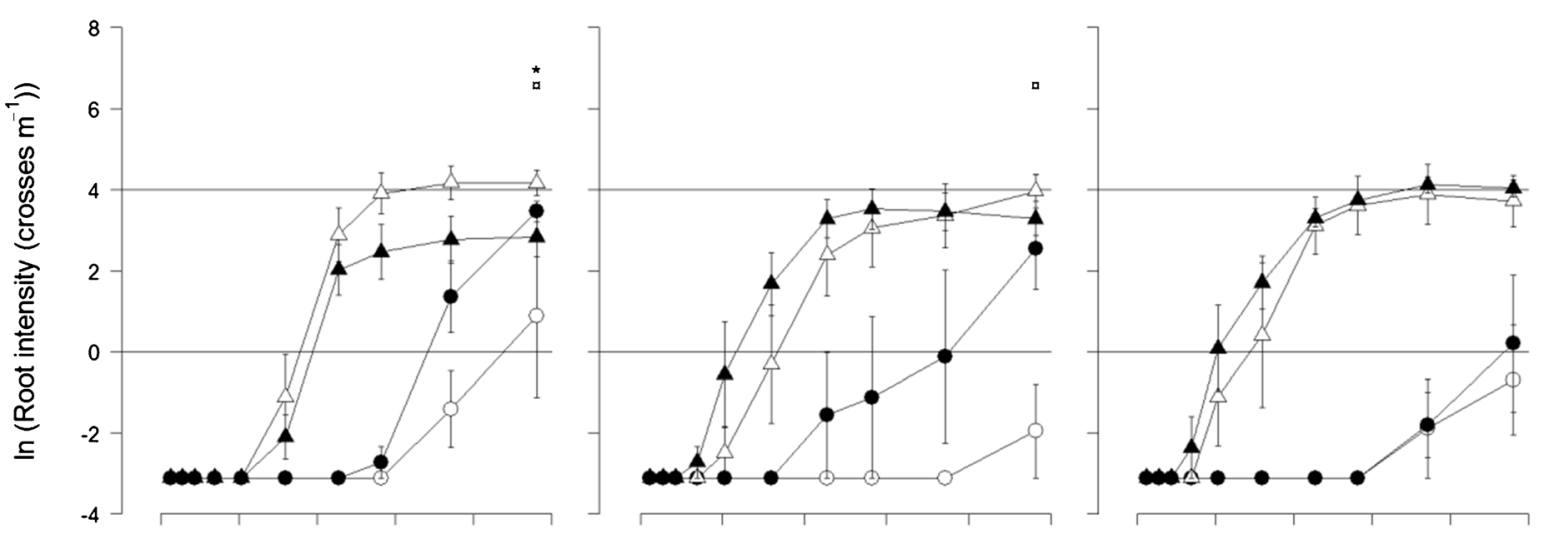

C
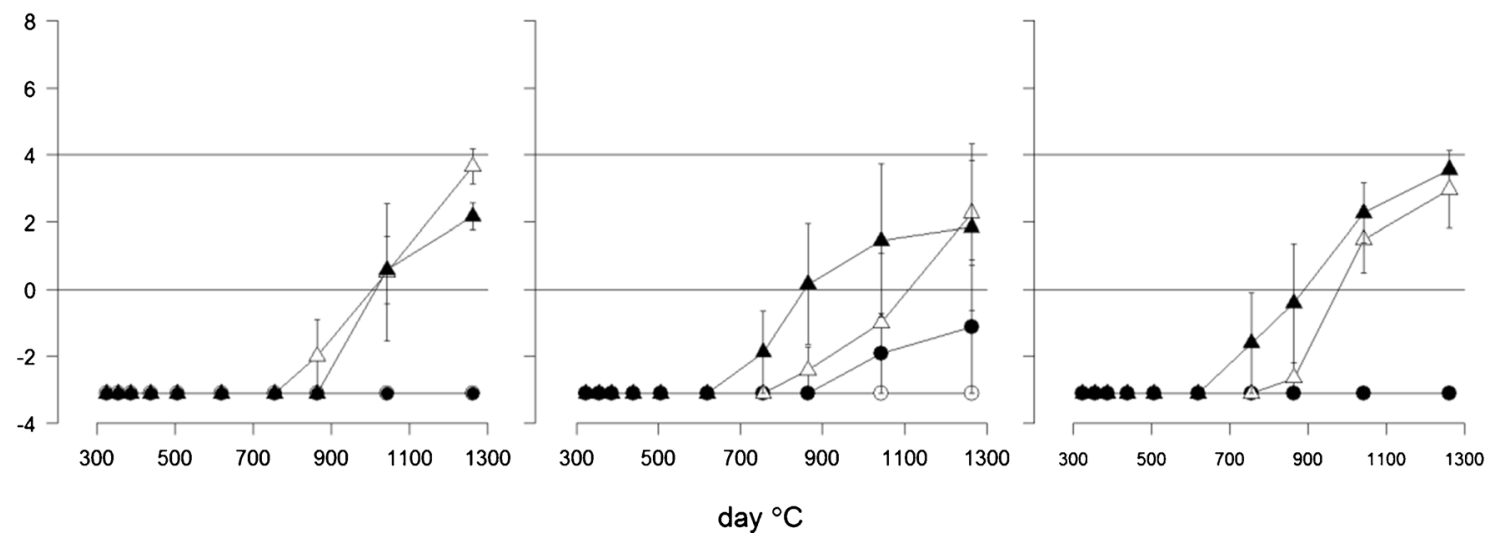

Fig. 4 Root intensity per plant in a the top soil layer $(0.02-$ $0.50 \mathrm{~m}), \mathbf{b}$ the middle soil layer $(0.50-1.02 \mathrm{~m})$ and $\mathbf{c}$ the bottom soil layer $\left(1.02-1.85 \mathrm{~m}\right.$ ) as a function of thermal time (day ${ }^{\circ} \mathrm{C}$ from transplanting) at low, medium and high $\mathrm{N}$ supply. Data were obtained on the underlined species when grown in mixture with

and Stern 1987a). Thus, red beet was the dominant component of the intercrop and clover the suppressed.

Red beet roots grew faster and significantly deeper than clover roots both in intercrop and sole crop (Fig. 3, Table 4), which is expected from previous root depth the species written in plain text. ' $*$ ' indicate significant difference $(p<0.05)$ between beet/clover and beet/beet and ' $\alpha$ ' indicate significant difference $\overline{(p<0} .05)$ between clover/clover and clover/beet at dates with a significant effect of $\mathrm{N}$ supply (see Table 3 for results of statistical analysis). Bars represent the mean $\pm \mathrm{SE}$

registrations of Trifolium species and Beta vulgaris varieties (Bennett and Doss 1960; Christiansen et al. 2006; Thorup-Kristensen 2006). The fast and deep root growth of red beet contributed to its dominance in the mixture as it was able to preempt soil $\mathrm{N}$ and other 
$0 \mathrm{~kg} \mathrm{~N} \mathrm{ha}^{-1}$

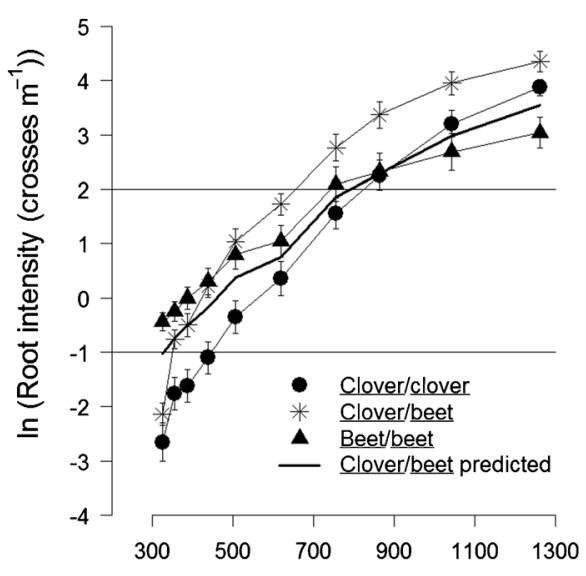

Fig. 5 Total Root intensity per rhizotron tube (two plants) in the whole soil column $(0-1.85 \mathrm{~m})$ as a function of thermal time (day ${ }^{\circ} \mathrm{C}$ from transplanting) at low, medium and high $\mathrm{N}$ supply. The

resources from a soil layer before the clover roots reached them. However, the decreased performance of clover at increased $\mathrm{N}$ supply was not likely to be caused by $\mathrm{N}$ deficiency, as root nodules were observed on its roots, and its $\mathrm{N}$ concentration was not reduced.. The $\mathrm{N}$ concentration in the aboveground biomass of clover was comparable with an $\mathrm{N}$ percent of 2.5-3.2 \% measured in red clover grown on a soil with a low $\mathrm{N}$ content (Ross et al. 2009) and 2.52-3.61\% measured in red clover

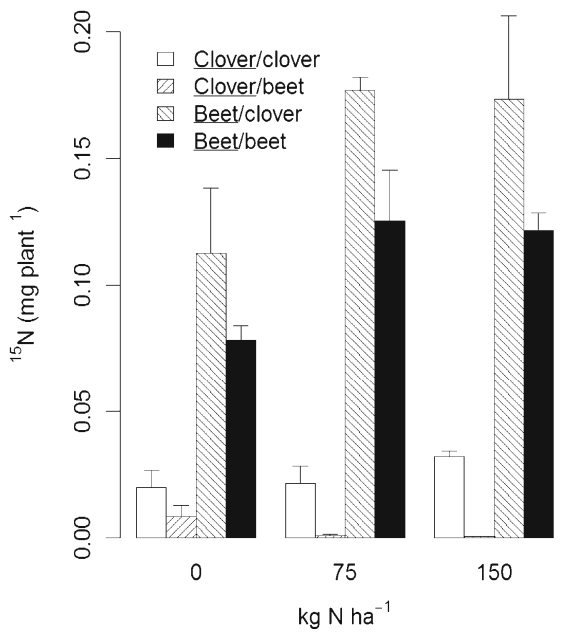

Fig. $6{ }^{15} \mathrm{~N}$ uptake per plant at harvest 3 days after injection of a ${ }^{15} \mathrm{~N}$ enriched solution in the soil column $0.62 \mathrm{~m}$ below the soil surface and root intensity in the $0.6-0.64 \mathrm{~m}$ soil layer around the injection depth. Data were obtained on the underlined species
$150 \mathrm{~kg} \mathrm{~N} \mathrm{ha}^{-1}$

$75 \mathrm{~kg} \mathrm{~N} \mathrm{ha}^{-1}$

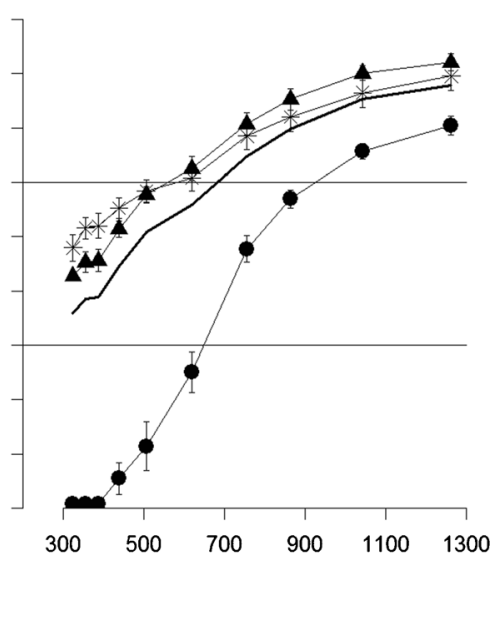

predicted root intensity in the mixture is shown as the sum of the root intensity for a single plant in the two sole crops $(0.5 \cdot \underline{\text { clover/ }}$ clover $+0.5 \cdot$ beet/beet). Bars represent the mean $\pm \mathrm{SE}$

grown in a mixture with timothy at $\mathrm{N}$ fertilization rates up to $160 \mathrm{~kg} \mathrm{~N} \mathrm{ha}^{-1}$ (Nesheim and Oyen 1994). Thus, the decreased performance of clover in mixture at increasing $\mathrm{N}$ supply may be caused by competition for other soil resources such as other macronutrients (P, K, $\mathrm{Ca}, \mathrm{Mg}$ or $\mathrm{S}$ ) or water.

Intercropping clover with red beet affected clover root growth, as it was inhibited in deeper soil layers where RI and root depth were lower for clover/beet than

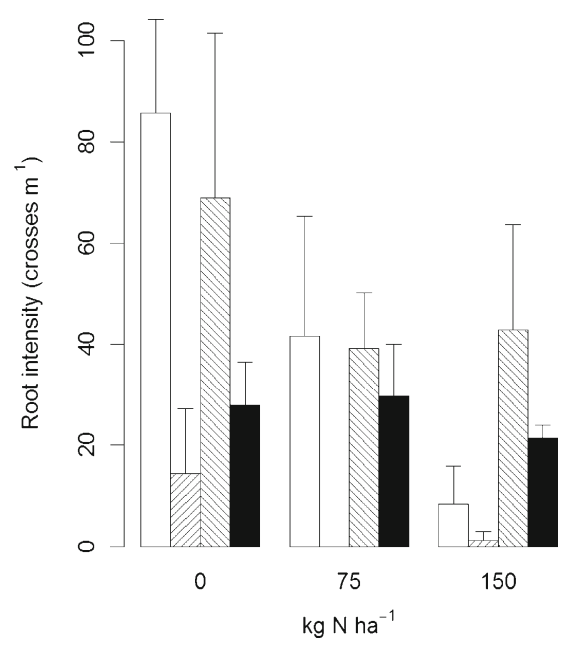

when grown in mixture with the species written in plain text. Bars with different letters below are significantly different $(p<0.05)$ within each $\mathrm{N}$ treatment. Bars represent the mean $+\mathrm{SE}$ 
for clover/clover (Fig. 4b). This inhibitory effect has been observed before on crimson clover and faba bean roots when they were grown with red beet (Tosti and Thorup-Kristensen 2010) and on faba bean when grown with maize ( $\mathrm{Li}$ et al. 2006), though the efficacy of the visual discrimination between the two root systems in the last work may be questioned. The response of clover to competition with red beet was mainly an effect of belowground interactions because the shoots were kept separated aboveground. The altered root growth of clover is a sign of root segregation through indirect interaction (Schenk et al. 1999). This can be a direct result of sensing a lower nutrient and water level, and/or the presence of red beet roots in this root zone (Hodge 2009), which triggers an overall feedback in the plant because there is less benefit of investing resources in root growth in this part of the soil. The ability of plants to discriminate between self and non-self roots is by now evident as a contributing mechanism of competitive root behavior in some plant species, though the mechanisms of self non-self recognition remains to be uncovered (Chen et al. 2012).

The ${ }^{15} \mathrm{~N}$ uptake confirmed the results from the root counting, showing that red clover in mixture did not grow as deep as red clover grown as sole crop, as clover/beet took up very little of the injected ${ }^{15} \mathrm{~N}$ compared to clover/ clover (Fig. 6). It is unlikely that the lower ${ }^{15} \mathrm{~N}$ uptake in red clover in mixture is a result of competition from red beet, because on average less than $6 \%$ of the injected $\mathrm{N}$ was taken up in each tube, indicating that red beet was not able to lower the ${ }^{15} \mathrm{~N}$ concentration in the root zone markedly during the period from injection until harvest.

The intercrop experiment was set up with a replacement design, which may confound effects of interspecific competition with that of intraspecific competition, because the density of each component in the mixture is different from that in its pure stand (Snaydon 1991). Results from a root study including red beet and crimson clover showed an effect of intraspecific competition on $\mathrm{RI}$, biomass and $\mathrm{N}$ yield for both species when comparing results from plants grown in rhizotron tubes at sole crop, single density, and double density (Tosti and Thorup-Kristensen 2010). Thus, the conclusions about the effects of competition can only be whether interactions between the two species differed from interactions within the species respectively.

Nitrogen fertilization affected the root growth of clover and red beet when grown as sole crops but less so when grown in mixture. Clover root depth and RI were lowered at high $\mathrm{N}$ supply when grown as sole crop, which eliminated the difference between clover root growth in mixture and in sole crop (Figs. 3, 4 and 5). Nitrogen can have a stimulating effect on root proliferation under some conditions (Robinson et al. 1999), but the response depends on the species and the $\mathrm{N}$ concentration. In a field study, the root length and biomass of tomato were found to increase up until $2 \mu \mathrm{g} \mathrm{NH}{ }_{4}{ }^{+}-\mathrm{N}$ and $6 \mu \mathrm{g} \mathrm{NO}_{3}{ }^{-}-\mathrm{N}$ per gram soil and then decrease again as the N supply was even higher (Bloom et al. 1993). When clover was grown with red beet, the RI was not lowered at the highest $\mathrm{N}$ supply, which could be because the concentration of $\mathrm{N}$ in the top soil was quickly decreased by red beet $\mathrm{N}$ uptake. However, legume root growth and behavior under high $\mathrm{N}$ levels are difficult to predict and explain, because $\mathrm{N}$-rich environments are not their natural habitat.

Red beet RI was lower at the lowest N supply compared to the medium and high $\mathrm{N}$ supply when grown as sole crop. Because RI in the mixture was less affected by the $\mathrm{N}$ level, the RI at low $\mathrm{N}$ supply ended up being lower when red beet was grown in sole crop compared to mixture, especially in the middle soil layer (Fig. 4). A strong effect of intraspecific competition on the root growth of red beet was demonstrated before (Tosti and Thorup-Kristensen 2010), and it seemed a result of an inherent intense soil exploration strategy. Since there was less competitive effect on the root growth of red beet at medium and high $\mathrm{N}$ supply, root growth might also be affected by resource supply. At the low $\mathrm{N}$ level red beet shoot growth was $\mathrm{N}$ limited which lowered the supply of photosynthetic products needed to produce new roots. At medium and high $\mathrm{N}$ supply, red beet total RI was higher and reached a common level which was similar to the total RI in mixture. Interestingly, there was a tendency that more roots were produced in the mixtures than would be predicted from the sole crops, indicating a mechanism which can lead to facilitation through increased soil exploitation in mixtures compared to sole crops. Results from previous experimental studies have indicated that plants sense and coordinate their root growth according to the available soil volume (Hess and De Kroon 2007; McConnaughay and Bazzaz 1991).

The two intercropped species expressed a clear difference in their general soil exploitation strategy and had different root distribution over time which influenced their access to soil resources. Red beet used resources on a fast and extensive root growth and the RI in the top soil leveled out or declined half way through the experiment 
while clover continued to increase its RI and became dominant down to $0.5 \mathrm{~m}$ soil depth in the later growth stages (Fig. 4). The same tendency was seen in a similar competition experiment with red beet/faba bean and red beet/crimson clover mixtures, where the RI of red beet in the top soil leveled out and the legumes kept increasing their RI both in mixture and in sole crop (Tosti and Thorup-Kristensen 2010). Clover species are considered shallow rooted and red clover may allocate more than $70 \%$ of its root biomass in the top $0.15 \mathrm{~m}$ of the soil (Bennett and Doss 1960) while the majority of the fibrous roots of sugar beet are located in deeper soil layers $(>0.30 \mathrm{~m})$ (Vamerali et al. 2003). The fact that the two species have different soil exploitation strategies gives them the opportunity to complement each other, which gives at least one species an advantage without a loss for any of them. The results indicate that this is mostly relevant at low $\mathrm{N}$ levels, as red beet biomass and RI was higher when intercropped and clover biomass was not significantly lower when intercropped compared to sole crop at the lowest $\mathrm{N}$ level.

The primary evaluation of the root growth was done by assessing the root intensity and root depth. Continuous measurement of RI and root depth has previously been evaluated as a good method for describing the morphology and dynamics of the root development (Tosti and Thorup-Kristensen 2010). RI calculated from counting root intercepts on a grid line is a synthetic indicator which may be comparable to direct measures of root systems such as root length (Tennant 1975) or root length density (Merrill and Upchurch 1994). However, a direct comparison between RI and nutrient uptake may not always be very clear. The results showed a weak correlation between ${ }^{15} \mathrm{~N}$ uptake and RI around the injection site ( $r=0.05$ for red beet and $r=0.25$ for clover). A much higher correlation was found between the aboveground biomass and the ${ }^{15} \mathrm{~N}$ uptake $(r=0.63$ for red beet and $r=0.70$ for clover). The reason for this may be that the labeled $\mathrm{N}$ was associated with nitrate and the main transport and uptake of nitrate- $\mathrm{N}$ happen by mass flow which is driven by transpiration. Over a longer period ( 2.5 months) in a study with catch crops, it was found that root frequency, the relative area on the rhizotron surface where roots are present in the given soil volume, was a better indicator of $\mathrm{N}$ uptake than RI (Thorup-Kristensen 2001).

Other factors than root growth and distribution affect the uptake and competition for soil N. In a modeling experiment Corre-Hellou et al. (2007) found that a deeper root depth penetration of barley in a mixture with pea could only explain the higher $\mathrm{N}$ uptake of barley compared to pea when the $\mathrm{N}$ supply was low. They hypothesized that the reason for this was that the limitation of the cereal growth made the $\mathrm{N}$ uptake almost as low as in the legume in the beginning of the crop cycle, so the soil $\mathrm{N}$ sharing in favor of barley must be explained by its deeper root growth. At higher $\mathrm{N}$ supply the difference in $\mathrm{N}$ demand was a better explanation for the higher $\mathrm{N}$ uptake of barley because the biomass production of barley responded positively and the pea biomass was rather unaffected by the $\mathrm{N}$ supply, and this created a big difference in $\mathrm{N}$ uptake (Corre-Hellou et al. 2007). Though the model used in the experiment with pea and barley needs to be tested and verified with other experiments the results indicate the importance of temporal nutrient demand and uptake in competition for nutrients. Hence, the deeper root growth of red beet is likely not the only reason for its greater uptake of soil $\mathrm{N}$ at higher $\mathrm{N}$ levels, but it makes it access soil resources before clover. The decreased performance of clover in mixture at increasing $\mathrm{N}$ supply was not evident in a further decreased root growth, but was more determined by the ability of red beet to utilize soil resources before clover and the increased red beet growth and demand for other soil resources at increasing $\mathrm{N}$ supply.

\section{Conclusion}

This study illustrates some of the mechanisms involved in the root interactions between components in intercrops of legumes and non-legumes which are valuable for designing profitable intercrop systems. It confirmed observations from other studies showing that the interspecific belowground competition resulted in a lower final biomass and $\mathrm{N}$ uptake of clover when intercropped with red beet and the effect was intensified with increasing $\mathrm{N}$ supply. The root foraging strategy of the two species differed. Red beet expressed a faster root depth penetration rate and achieved higher root intensity from the beginning which made red beet a stronger competitor for $\mathrm{N}$ and other soil resources. Clover root growth was slower but continued for longer and at the end of the experiment it was dominant in the top soil while red beet roots still dominated the deeper soil layers.

Intercropping affected clover root growth as the root intensity was decreased in deeper soil layers when grown in competition with red beet. Increased $\mathrm{N}$ supply 
did not affect the root growth of clover in mixture but reduced total root intensity and root depth of clover when grown as sole crop. Red beet root growth was most affected by intercropping at low $\mathrm{N}$ supply where the root intensity did not reach the same level in sole crop as in mixture because of a high intraspecific competition.

Since the root dynamics of the two species in mixture compared to sole crop was not changed dramatically at increased $\mathrm{N}$ supply, the increased dominance of red beet at higher $\mathrm{N}$ level was likely due to its increased aboveground growth and competitiveness for other soil resources.

Acknowledgments The authors thank Giacomo Tosti, University of Perugia, Italy, for critical reading and commenting the manuscript.

\section{References}

Andersen M, Hauggaard-Nielsen H, Ambus P, Jensen E (2004) Biomass production, symbiotic nitrogen fixation and inorganic $\mathrm{N}$ use in dual and tri-component annual intercrops. Plant Soil 266:273-287

Båth B, Kristensen HL, Thorup-Kristensen K (2008) Root pruning reduces root competition and increases crop growth in a living mulch cropping system. J Plant Interact 3:211-221

Bennett O, Doss B (1960) Effect of soil moisture level on root distribution of cool-season forage species. Agron J 52:204 207

Bloom A, Jackson L, Smart D (1993) Root-growth as a function of ammonium and nitrate in the root zone. Plant Cell Environ 16:199-206

Chen BJW, During HJ, Anten NPR (2012) Detect thy neighbor: identity recognition at the root level in plants. Plant Sci 195: $157-167$

Christiansen JS, Thorup-Kristensen K, Kristensen HL (2006) Root development of beetroot, sweet corn and celeriac, and soil $\mathrm{N}$ content after incorporation of green manure. J Hortic Sci Biotechnol 81:831-838

Connolly J, Goma H, Rahim K (2001) The information content of indicators in intercropping research. Agric Ecosyst Environ 87:191-207

Corre-Hellou G, Crozat Y (2005) Assessment of root system dynamics of species grown in mixtures under field conditions using herbicide injection and $\mathrm{N}-15$ natural abundance methods: a case study with pea, barley and mustard. Plant Soil 276:177-192

Corre-Hellou G, Fustec J, Crozat Y (2006) Interspecific competition for soil $\mathrm{N}$ and its interaction with $\mathrm{N}-2$ fixation, leaf expansion and crop growth in pea-barley intercrops. Plant Soil 282:195-208

Corre-Hellou G, Brisson N, Launay M, Fustec J, Crozat Y (2007) Effect of root depth penetration on soil nitrogen competitive interactions and dry matter production in pea-barley intercrops given different soil nitrogen supplies. Field Crop Res 103:76-85

Fitter A (1996) Characteristics and functions of root systems. In: Waisel Y, Eshel A, Kafkafi U (eds) Plant roots the hidden half, 2nd edn. Marcel Dekker, New York, pp 1-20

Hauggaard-Nielsen H, Ambus P, Jensen ES (2001) Temporal and spatial distribution of roots and competition for nitrogen in pea-barley intercrops - a field study employing P-32 technique. Plant Soil 236:63-74

Hess L, De Kroon H (2007) Effects of rooting volume and nutrient availability as an alternative explanation for root self/non-self discrimination. J Ecol 95:241-251

Hodge A (2009) Root decisions. Plant Cell Environ 32:628-640

Jensen ES (1996) Grain yield, symbiotic N-2 fixation and interspecific competition for inorganic $\mathrm{N}$ in pea-barley intercrops. Plant Soil 182:25-38

Katayama K, Ito O, Matsunaga R, AduGyamfi JJ, Rao TP, Anders MM, Lee KK (1995) Nitrogen balance and root behavior in four pigeonpea-based intercropping systems. Fert Res 42: 315-319

Li L, Sun J, Zhang F, Guo T, Bao X, Smith F, Smith S (2006) Root distribution and interactions between intercropped species. Oecologia 147:280-290

McConnaughay K, Bazzaz F (1991) Is physical space a soil resource. Ecology 72:94-103

Merrill S, Upchurch D (1994) Converting root numbers observed at minirhizotrons to equivalent root length density. Soil Sci Soc Am J 58:1061-1067

Morgado L, Willey R (2003) Effects of plant population and nitrogen fertilizer on yield and efficiency of maize-bean intercropping. Pesq Agrop Brasileira 38:1257-1264

Nesheim L, Oyen J (1994) Nitrogen-fixation by red-clover (Trifolium pratense L.) grown in mixtures with timothy (Phleum pratense L.) at different levels of nitrogen fertilization. Acta Agric Scand 44:28-34

Ofori F, Stern WR (1986) Maize cowpea intercrop system — effect of nitrogen fertilizer on productivity and efficiency. Field Crop Res 14:247-261

Ofori F, Stern WR (1987a) The combined effects of nitrogen fertilizer and density of the legume component on production efficiency in a maize cowpea intercrop system. Field Crop Res 16:43-52

Ofori F, Stern WR (1987b) Cereal-legume intercropping systems. Adv Agron 41:41-90

R Development Core Team (2011) R: A language and environment for statistical computing. R Foundation for Statistical Computing, Vienna, Austria. ISBN 3-900051-07-0, URL http://www.R-project.org

Rewald B, Meinen C, Trockenbrodt M, Ephrath J, Rachmilevitch S (2012) Root taxa identification in plant mixtures - current techniques and future challenges. Plant Soil 359:165-182

Robinson D, Hodge A, Griffiths BS, Fitter AH (1999) Plant root proliferation in nitrogen - rich patches confers competitive advantage. Proc R Soc Lond 266:431-435

Ross SM, King JR, Izaurralde RC, O'Donovan JT (2009) The green manure value of seven clover species grown as annual crops on low and high fertility temperate soils. Can J Plant Sci 89:465-476

Saxton KE, Rawls WJ (2006) Soil water characteristic estimates by texture and organic matter for hydrologic solutions. Soil Sci Soc Am J 70:1569-1578 
Schenk HJ, Callaway RM, Mahall BE (1999) Spatial root segregation: are plants territorial? Adv Ecol Res 28:145-180

Semere T, Froud-Williams R (2001) The effect of pea cultivar and water stress on root and shoot competition between vegetative plants of maize and pea. J Appl Ecol 38:137145

Snaydon R (1991) Replacement or additive designs for competition studies. J Appl Ecol 28:930-946

Tennant D (1975) Test of a modified line intersect method of estimating root length. J Ecol 63:995-1001

Thorsted MD, Weiner J, Olesen JE (2006) Above- and belowground competition between intercropped winter wheat Triticum aestivum and white clover Trifolium repens. J Appl Ecol 43:237-245

Thorup-Kristensen K (2001) Are differences in root growth of nitrogen catch crops important for their ability to reduce soil
nitrate-N content, and how can this be measured? Plant Soil 230:185-195

Thorup-Kristensen K (2006) Effect of deep and shallow root systems on the dynamics of soil inorganic $\mathrm{N}$ during three year crop rotations. Plant Soil 288:233-248

Tosti G, Thorup-Kristensen K (2010) Using coloured roots to study root interaction and competition in intercropped legumes and non-legumes. J Plant Ecol 3:191-199

Vamerali T, Ganis A, Bona S, Mosca G (2003) Fibrous root turnover and growth in sugar beet (Beta vulgaris var. saccharifera) as affected by nitrogen shortage. Plant Soil 255:169-177

Vandermeer J (1989) The ecology of intercropping. Cambridge University Press, Cambridge

Vitoria L, Otero N, Soler A, Canals A (2004) Fertilizer characterization: isotopic data (N, S, O, C, and $\mathrm{Sr}$ ). Environ Sci Technol 38:3254-3262 